Journal of Management Science (JMAS)

Volume 4. No. 4 October 2021, pp 118-123

e-ISSN: 2684-9747

https://iocscience.org/ejournal/index.php/JMAS

\title{
Measurement Of Customer Loyalty On Products Indonesian Brands With Net Promoter Score (NPS) Method In Medan City Middle Class Consumers
}

\author{
Natashya Situmorang \\ Management Study Program, Faculty Of Economics, University Of North Sumatra, \\ Medan \\ E-mail: natashyasitumorang@gmail.com
}

\begin{abstract}
ARTICLE INFO
ABSTRACT

Article history:

Received: 12 August 2021

Revised: 19 September 2021

Accepted: 30 October 2021

Keywords:

Loyalty;

Net Promoter Score (NPS);

Customer Experience;

Middle Class.

The increasing number of graduates from universities who already have jobs have resulted in the rapid growth of one of the categories of middle class society in Indonesia. Indirectly it has an impact on increasing income which results in changes in lifestyle and purchasing power as well as changes in the choice of brands used by a person. Various kinds of products that are classified as luxury goods have now become a necessity for supporting the lifestyle of the middle class in this modern era. This middle class consumer is included in the Climber Middle Class category which is the largest segment among the 8 Middle Class Faces. And generally Climbers are known as hard-working figures who try to improve their economic status, are highly educated, do not have much experience (just got a job or are still building their careers) and tend to be the backbone of the family. This research was conducted using the Net Promoter Score (NPS) method which was then continued by measuring the customer experience (Customer Experience) through the touch point (moment of truth) of each brand studied. The number of population in this study is unknown, so the sample used is 125 respondents. Secondary data were also collected through books, magazines, and literature to support the analysis in this study. This method uses quantitative descriptive analysis. The results of this study indicate that there are 25 brands out of 96 brands studied that have a negative Net Promoter Score (NPS).
\end{abstract}

\section{Introduction}

The increasing number of graduates from universities who already have jobs have resulted in the rapid growth of one of the categories of middle class society in Indonesia. Indirectly, this has an impact on changes in the lifestyle of the graduate. The increase in income has boosted the purchasing power of middle class consumers, which now shows that products that were previously only consumed by the upper class can now be consumed by many. Various kinds of products that are classified as luxury goods have now become a necessity to support the lifestyle of the middle class in this modern era.

The level of income now owned by graduates who are already working has an impact on activities to consume luxury goods that previously could not be owned. It also brings changes to the brand selection on the products used. The increase in the lifestyle of the middle class resulted in a revolution on the side of the middle class producers which triggered the emergence of changes in values or called Value Innovators by Prof. Chan Kim from INSEAD. Value Innovators are players who are able to create breakthrough products and services through value innovation, by increasing benefits (benefits) to the sky as well as lowering customer costs as low as possible. This concept is carried out by successful players targeting the middle class as consumers or service users.

The middle class tends to have fewer children than the poor, and a large portion of its income is allocated to education. They generally have the awareness to invest in human resources by sending their children to school, not only at the elementary level, but also to a higher level. Compared to the poor, the middle class also goes to the doctor more often and enjoys health services that are more expensive. Not 
surprisingly, the share of their spending on health increased sharply as income increased. In short, the middle class is a group of people with a better quality of life. They enjoy better education, better health, bigger and more expensive homes, better quality food, and they begin to enjoy adequate entertainment.

The Climber category has the largest size among other segments, which is $21.51 \%$. The second one is Performer (18.1\%), and Aspirator (16.69\%), Flow-er (16.06\%), Follower (13.94\%), Settler (6.29\%), Trendsetter $(5,62 \%)$, and the smallest is Expert $(1.87 \%)$. The size of this market was obtained through a quantitative survey conducted face-to-face using stratified random sampling on 2510 respondents in 9 major cities consisting of Greater Jakarta, Surabaya, Denpasar, Medan, Yogyakarta, Balikpapan, Bandung, Semarang, and Makassar (Yuswohady and Kemal, 2015 :83)

The Climber category is a middle class figure who is quite well educated and does not have that much experience. That way, Climber's motivation is to find the best career for himself by considering the financial aspects he receives and the career guarantees that he will get from his workplace. Not infrequently, this figure takes the risk of leaving his original office to get a better career.

Climber is a picture of the middle class who is known as a hard worker, who is driven by the desire to improve economic status, get better welfare, as well as a form of appreciation from the place where he works. Climbers have high family values and work hard for the family, and tend to be the backbone of the family. Therefore, they are the figure of "hero of their family". Therefore, the Climber is very concerned about improving his skills, and pays little attention to the importance of being socially connected. (Yuswohady and Kemal, 2015: 71).

The rapid development of innovation made by manufacturers has resulted in a large number of various branded products developing in the market, so that consumers are faced with a wide choice of products with different quality levels. Companies choose to innovate their products with the times in order to be able to attract this middle class, the difficulty of predicting the character of the middle class society makes companies no longer able to demand consumer loyalty as a commitment to use their products continuously or in the long term.

The number of competitors who offer various brands of similar products and have many similarities ranging from shapes, attributes and various other variations makes it increasingly difficult for consumers to distinguish between the advantages and disadvantages of one brand with another. Not to mention the emergence of products with better quality at lower prices, making companies have to be more sensitive in reading consumer needs. Therefore, now that companies can no longer measure customer loyalty with the promise of the best product service, consumers need reasons that are higher than just functional and emotional advantages. They have spiritual values that the company offers to consumers (Kartajaya; 2007: 2021).

The value received by customers according to Situmorang (2012: 205-206) is "the ratio between the total customer value and the total customer cost. The total customer value is the number of benefits that customers expect from the purchased product, while the total customer cost is the total cost incurred by the customer to get the product. If the total customer value is greater than the total customer cost, then the customer will feel benefited or satisfied, and vice versa.

Satisfied consumers will be loyal and tell the goodness of the product to others, so that it can increase the number of consumers of a brand's product. The more consumers, the greater the income that can be achieved by the company, on the contrary, the fewer consumers, the less income the company can achieve. Consumer satisfaction is the level of a person's feelings after comparing the performance (or results) he feels compared to his expectations (Kotler, 2009: 138) The method used to measure customer loyalty is the Net Promoter Score method. The Net Promoter Score method developed by Fred Reichheld in his book The Ultimate Question, the Net Promoter Score (NPS) is a very simple loyalty measurement model. This method serves to measure how strong the brand is and how much the brand wants to be recommended by customers compared to other brands. The NPS value can also be used to compare customer loyalty between one company/business and another.

The Net Promoter Score (NPS) method is a very simple but easy to understand and effective method for measuring the level of loyalty, so this method is widely used. NPS is the percentage of Promoters minus the percentage of Detractors presented in an easy-to-understand way, and also the most effective short summary of how a company is running (Reichheld; 2011: 40).

\section{Method}

This type of research uses quantitative descriptive research. Quantitative Descriptive is a research method 
based on the philosophy of positivism, used to examine certain populations or samples, sampling techniques are generally carried out randomly, data collection uses research instruments, data analysis is quantitative/statistical with the aim of testing predetermined hypotheses. (Sugiyono, 2011: 15).

This research was carried out on Middle Class Consumers in the city of Medan who are included in the Climber category, namely aged between 25-40 years, fairly high education, having not so much experience (just getting a job or those who are still starting their career), a minimum of 2 years working, who still like to change jobs, tend to be the backbone of the family, and have a minimum income of IDR 2,000,000. Time Research will start in September-October 2016.

Sugiyono (2012: 119) suggests that the population is a generalization area consisting of: objects/subjects that have certain qualities and characteristics determined by researchers to be studied and then to draw conclusions. The population of this study includes Middle Class Consumers.

The sample is a number of members selected from the population. Sugiyono (2012:120) argues that the sample is part of the number and characteristics possessed by the population.

In this study, using purposive sampling technique, namely the way the sample was selected was carried out with certain considerations and criteria. The criteria used as samples in this study were the Climber category aged 25-40 years, with fairly high education, having not so much experience (just getting a job or still starting their career), working at least 2 years, those who still like to change jobs, tend to become the breadwinner of the family, and have a minimum income of IDR 2,000,000. Because the total population in this study is not clearly known, the number of samples that will be used in this study is 125 respondents.

The types of data used are primary data and secondary data, primary data is data collected by individuals/organizations directly from the object under study and for the benefit of the study concerned in the form of interviews, observations (Situmorang and Lutfi, 2012:3). The primary data in this research is the respondent's answer data which is sourced from the questionnaire. Secondary data is data obtained/collected and put together by previous studies or published by various other agencies (Situmorang and Lutfi, 2012:3).

The method of data collection was carried out by questionnaires, the questionnaire, namely data collection was carried out by giving a list of questions to selected respondents regarding the Net Promoter Score. Interviews, conducting direct communication and question and answer with respondents to obtain maximum research results, and documentation studies, collecting data through information from books, articles, magazines and the internet that have relevance to the research.

\section{Results and Discussion}

\section{Respondent's description}

This research was conducted on Middle Class Consumers in Medan City, namely in the Climber Category as many as 125 respondents who can be grouped based on Age, Gender, Education, Length of Work, and a minimum monthly income of IDR 2,000,000.-.

Table 1. Number of Respondents by Age

\begin{tabular}{|c|c|c|}
\hline Age & Amount & Percentage \\
\hline $25-30$ Years & 89 people & $72 \%$ \\
\hline $31-35$ Years & 18 people & $14 \%$ \\
\hline $36-40$ Years & 18 people & $14 \%$ \\
\hline
\end{tabular}

In Table 1 it can be seen that the number of middle class consumers, namely the Climber category in the city of Medan based on their age, is 89 respondents (72\%) aged between 25-30 years, 18 respondents (14\%) aged between 31-35 years, and 18 respondents (14\%) are between 36-40 years old.

Table 2. Number of Respondents by Gender

\begin{tabular}{|c|c|c|}
\hline Gender & Amount & Percentage \\
\hline Woman & 79 people & $63 \%$ \\
\hline Male & 46 People & $37 \%$ \\
\hline
\end{tabular}




\section{Journal of Management Science (JMAS)}

Volume 4. No. 4 October 2021, pp 113-117

https://iocscience.org/ejournal/index.php/JMAS

In Table 2 it can be seen that the number of middle class consumers, namely the Climber category in the city of Medan based on gender, is 79 respondents (63\%) are female, 46 respondents (37\%) are male.

Table 3. Number of Respondents Based on Education

\begin{tabular}{|c|c|c|}
\hline Education & Amount & Percentage \\
\hline Diploma & 48 People & $38 \%$ \\
\hline S1 & 68 People & $55 \%$ \\
\hline S2 & 9 people & $7 \%$ \\
\hline
\end{tabular}

Source: Research Results, 2016 (Processed Data)

In Table 3 it can be seen that the number of middle class consumers, namely the Climber category in the city of Medan based on education, is 48 respondents (38\%) with diploma education, 68 respondents $(55 \%)$ with undergraduate education and 9 respondents (7\%) with masters education.

Table 4. Number of Respondents Based on Length of Work

\begin{tabular}{|c|c|c|}
\hline Length of work & Amount & Percentage \\
\hline 25 years & 95 People & $76 \%$ \\
\hline 6- 10 Years & 18 people & $14 \%$ \\
\hline $11-15$ Years & 12 people & $10 \%$ \\
\hline
\end{tabular}

Source: Research Results, 2016 (Processed Data)

In Table 4 it can be seen that the number of Middle Class Consumer respondents, namely the Climber Category in the city of Medan based on Length of Work, is 95 respondents (76\%) have worked for 2-5 years, 18 respondents $(14 \%)$ have worked for 6-10 years. , 12 respondents $(10 \%)$ have worked for 11-15 years.

Table 5. Number of Respondents Based on Income/month

\begin{tabular}{|c|c|c|}
\hline Income/month & Amount & Percentage \\
\hline IDR 2,000,000,- - IDR 3,500,000,- & 62 people & $50 \%$ \\
\hline IDR 3,500,001,- - IDR 5,000,000 & 43 People & $34 \%$ \\
\hline More than IDR 5,000,001,- & 20 people & $16 \%$ \\
\hline
\end{tabular}

In Table 5 it can be seen that the number of middle class consumers, namely the Climber Category in the city of Medan based on income/month, is 62 respondents (50\%) who have an income of Rp. 2,000,000.- to Rp. 3,500,000,-, 43 respondents (34\%) have an income/month of Rp. 3,500,000,- to Rp. 5,000,000,-, and 20 respondents (16\%) have an income/month of more than Rp. 5,000,000,-

\section{Distribution of Respondents' Answers Clothing Category}

Distribution of Respondents' Answers for Clothing Category can be seen in Table 4.6 below:

Table 6. Distribution of Respondents' Answers Clothing Category

\begin{tabular}{|c|c|c|c|c|c|c|}
\hline No & Brand & $\begin{array}{c}\text { Promoter } \\
(\boldsymbol{\%})\end{array}$ & $\begin{array}{c}\text { Passive } \\
(\boldsymbol{\%})\end{array}$ & $\begin{array}{c}\text { Detractor } \\
(\boldsymbol{\%})\end{array}$ & $\begin{array}{c}\text { NPS } \\
\text { Value } \\
(\boldsymbol{\%})\end{array}$ & $\begin{array}{c}\text { Category } \\
\text { NPS }\end{array}$ \\
\hline 1. & $\begin{array}{c}\text { The } \\
\text { Executive }\end{array}$ & 19 & 87 & 19 & 0 & Excellent \\
\hline 2. & Polo & 20 & 95 & 10 & -7 & 19 \\
\hline 3. & Cole & 8 & 102 & 10 & $\begin{array}{c}\text { Leaders/ } \\
\text { Excellent }\end{array}$ \\
\hline 4. & mango & 19 & 106 & 20 & 4 & good \\
\hline 5. & H\&M & 24 & 81 & & & \\
\hline
\end{tabular}


Journal of Management Science (JMAS)

Volume 4. No. 4 October 2021, pp 118-123

e-ISSN: 2684-9747 https://iocscience.org/ejournal/index.php/JMAS

Distribution of Respondents' Answers in Watch Category

The distribution of respondents' answers in the watch category can be seen in Table 9 below:

Table 7. Distribution of Respondents' Answers in Watch Category

\begin{tabular}{|c|c|c|c|c|c|c|}
\hline No. & Brand & $\begin{array}{c}\text { Promoter } \\
(\boldsymbol{\%})\end{array}$ & $\begin{array}{c}\text { Passive } \\
(\boldsymbol{\%})\end{array}$ & $\begin{array}{c}\text { Detractor } \\
(\boldsymbol{\%})\end{array}$ & $\begin{array}{c}\text { NPS } \\
\text { Value } \\
(\boldsymbol{\%})\end{array}$ & $\begin{array}{c}\text { Category } \\
\text { NPS }\end{array}$ \\
\hline 1. & Alba & 18 & 103 & 4 & 14 & Excellent \\
\hline 2. & Seiko & 38 & 81 & 6 & 32 & Excellent \\
\hline 3. & $\begin{array}{c}\text { Switzerland } \\
\text { Army }\end{array}$ & 14 & 101 & 10 & 4 & good \\
\hline 4. & Guess & 48 & 70 & 7 & 41 & Excellent \\
\hline 5. & $\begin{array}{c}\text { Alexander } \\
\text { Christie }\end{array}$ & 45 & 77 & 3 & 42 & $\begin{array}{c}\text { Leader/ } \\
\text { Excellent }\end{array}$ \\
\hline 6 & Casio & 24 & 95 & 6 & 18 & Excellent \\
\hline
\end{tabular}

Source: Research Results, 2016 (Processed Data)

\section{Conclusion}

Based on the results of the analysis and discussion that have been stated previously, the conclusions of this study are as follows: There are 20 categories consisting of 96 brands. Of the 96 brands, there are brands that do not have a Net Promoter Score (NPS) or 0. There are 4 brands, namely The Executive in the Clothing category, Volcom from the Wallet category, Books \& Beyond from the Bookstore category, and Nusatrip from the Travel Portal category. And as many as 25 brands have a negative Net Promoter Score (NPS).

Brands that are included in the Net Promoter Score (NPS) in the STAR category are Apple in the Gadget category with a Net Promoter Score (NPS) of 61\%. In addition, there are 20 brands in the leader category, in the Excellent category there are 58 brands, and in the Good category there are 9 brands. The brand that obtained the highest average Customer Experience (CE) of all the brands studied was Vans from the Sneakers category at $8.11 \%$ and the brand that obtained the lowest average value of Customer Experience (CE) was Bumiputera from the Insurance category of $6,74 \%$.

In the Jeans Category, the Lois brand, which is a multinational brand, received a Net Promoter Score (NPS) of $48 \%$, while the Lea brand, which is a national brand, received a Net Promoter Score (NPS) of $28 \%$. This means that in the Jeans category, Multinational Brands are superior to National brands. Meanwhile, in the Department Store category, it can be seen that the comparison between National and Multinational brands shows that Matahari which is a National brand has a Net Promoter Score (NPS) of 32\%, while Parkson, a Multinational brand, has $27 \%$. And in the Aviation category, Citilink, which is a national brand, received a Net Promoter Score (NPS) of 17\%, while Air Asia, which is a multinational brand, obtained a Net Promoter Score (NPS) of $9 \%$.

\section{References}

Aaker, David, 2015. Aaker On Branding: 20 Principles That Drive Success, PT Gramedia Utama, Jakarta.

Johnson, Michael D. and Anders Gustafsson, 2000. Improving Customer Statisfaction, Loyalty, and Profit: an Integrated measurement and management system, Jossey-Bass, San Francisco.

Kartajaya, Hermawan, 2007. Boosting Loyalty Marketing Performance, PT Mizan Library, Jakarta.

Kotler, P. and Keller, KL, 2009. Marketing Management, Edition 13 Volume 1, PT Index Publisher, Jakarta.

Kosmedi, Indra, 2015. Measurement of customer loyalty in Indonesia's Top Brand Products using the Net Promoter Score Method, Thesis, Medan.

Meyer, Christopher and Andre Schwager. 2007. Understanding Customer Experience. Harvard Business Review

Okonkwo, Uche, 2007. Luxury Fashion Branding: Trends, Tactics, Techniques, Palgrave MacMillan, New York.

Reichheld, Fred, 2011. The Ultimate Question 2.0 (How Net Promoter Companies Thrive in a Customer-Driven World), Harvard Business Review Press, Cambridge.

Shaw, Colin and John Ivens. 2002. Building Great Customer Experience. New York: Macmillan Palgrave.

Situmorang, Syafrizal Helmi, 2012. Business Concepts and Cases, USU Press, Medan.

Sugiyono, 2011. Qualitative Quantitative Research Methods and R\&D. Alfabeta, Bandung 2012. Educational Research Methods. Alfabeta, Bandung. 
Suyanto, M. 2007. Marketing Strategy of Top Brand Indonesia, Andi Publisher, Jogjakarta.

Szwarc, Paul, 2005. Researching customer satisfaction and loyalty, British Library Cataloging-in-Publication Data, London..

Yuswohady and Gani, Kemal E. 2015, 8 Faces of the Middle Class. Publisher PT Gramedia Pustaka Utama, Jakarta.

Anindito, Degree Hasti, 2011. Analysis of the Effect of Relationship Dimension Index (RDI) on Net Promoter Score (NPS) to increase PT Telkom's corporate customer loyalty. http://digilib.its.ac.id/public/ITS-Undergraduate-16768presentation.pdf(27 October 2016).

Court, David, et al. The Consumer Decision journey. http://www.mckinsey.com/business-functions/marketing-andsales/our-insights/the-consumer-decision-journey\&prev=search.(August 6, 2016).

Herianto, Nadia Amanda, 2015. Customer Satisfaction Versus Customer Loyalty.https://subiz.com/blog/kepuasanpelanggan-versus-loyalty- customer.html. (July 23. 2016).

Kusumawati, Ika P, 2013. Analysis of the Effect of Customer Experience on repurchase intention (Case Study on consumers of The House Of Raminten Restaurant, Yogyakarta. (October 27, 2016).

Top Brand Award, 2011. Top Brand Barometer of Brand Strength. http://www.topbrand-award.com/article/top-brandbarometer-power- brand.html.(July 23. 2016).

Reza, Eka W, 2016. The Influence of Customer Experience on Customer Loyalty with customer satisfaction as an intervening variable (study on Mie Rampok Prisoners in Surabaya).

Republic of Indonesia, 2001. Law No. 15 concerning Marks. State Gazette of the Republic of Indonesia year 2000, Number 243. State Secretariat, Jakarta. 